\title{
A novel German guideline for the sampling procedures for passive biomonitoring with fish as accumulation indicators: VDI 4230, Part 4
}

\author{
Roland Klein ${ }^{1}$, Jens Gercken², Herbert Löffler ${ }^{3}$, Theo von der Trenck ${ }^{4}$ and Thomas Braunbeck ${ }^{{ }^{*}}$
}

\begin{abstract}
A novel German guideline, VDI 4230, Part 4, has been adopted to provide a standardized protocol for the sampling of freshwater fish for passive biomonitoring with fish as accumulation indicators. The guideline has been designed for multiple purposes, e.g. for the chronological tracking of environmental pollution following hazardous incidents, for the monitoring of the success of regulatory measures and voluntary restrictions, for emission and immission monitoring, for the monitoring of contaminated sites, for the provision of samples retained for long-term monitoring, and for initial exploratory studies for determination of pollution hotspots.
\end{abstract}

Biological methods are important tools in environmental risk assessment and pollution monitoring. Fish are especially well-suited indicators for aquatic ecosystems due to their longevity, their ability for spatial and temporal integration, as well as their availability in different water types. In contrast to non-vertebrate bioindicators, fish allow a more direct transfer of observations to humans. Thus, especially for many highly lipophilic compounds they may also serve as indicators for the risk of humans to accumulate contaminants via the food chain. For these reasons, the new national guideline VDI 4230, Part 4, addresses fish as indicators of accumulation. As part of a comprehensive VDI guideline series on bioindication in wildlife, it provides standardized protocols for the sampling of fish in biomonitoring.

Monitoring the environmental status and the definition of environmental quality standards and objectives play an increasingly important role, especially in environmental policy. With the adoption of the Water Framework Directive 2000/60/EC (WFD [1]), the European Union

\footnotetext{
*Correspondence: braunbeck@uni-hd.de

${ }^{5}$ Aquatic Ecology and Toxicology Group, Center for Organismal Studies, University of Heidelberg, Im Neuenheimer Feld 504, 69120 Heidelberg, Germany

Full list of author information is available at the end of the article
}

has taken great strides towards the protection of aquatic environments. The aim of this directive is to reach and guarantee a good ecological and chemical status of water bodies. In this context, the German Federal States' Water Consortium (LAWA) specifically developed a concept for biota studies for the monitoring of priority substances [2] in compliance with the European Directive 2008/105/ EC [3]. This biota concept is currently under revision to implement European Directive 2013/39/EU [4]. In contrast to the LAWA concept, the new VDI guideline provides a detailed set of operational procedures applicable to many additional cases in the context of biomonitoring.

The new VDI guideline has been developed on the basis of an existing guideline for sampling and sample processing by the Federal German Environmental Specimen Bank [5]. The new guideline integrates the contents of this guideline and develops it further for additional purposes and fish species.

A reliable assessment of surface waters based on biota data strongly depends upon the availability of high-quality samples. Hence, sampling procedures are of crucial importance, because sampling errors cannot be corrected or mitigated at a later stage. Standardization of sampling procedures is the most important tool to assure a high degree of reproducibility without losing representativity. 
The new guideline meets these requirements: It provides comprehensive descriptions of the principles and implementations of procedures and also gives advice on documentation and quality assurance to avoid artefacts, to minimize the loss of biological information and to cope with the high variability of biological samples. The selection of target species according to well-defined criteria as well as the selection of target compartments are crucial steps in the sampling process. Their implementation is extensively described and encompasses many different steps and requirements. These include, for example, species identification, legal requirements and approvals, selection and number of individuals, sampling period, recommended equipment and cleaning procedures, sampling technique, and sample transport. Individual operational steps are not only specified in detail, but are also well-founded and accounted for. This provides potential users with the necessary insight to apply and to adjust the various procedures to their own specific requirements by providing standard descriptions for sampling procedures including planning, catching the fish, as well as sampling and handling of tissues. Further information and tools for high-quality sampling are provided in two appendices: Appendix I focuses on age determination of fish using gill covers (opercula) or further ossifications. Appendix II gives examples of data sheets for a comprehensive documentation of the sampling design and techniques, as well as fish data.

The guideline is limited to fish from freshwater habitats and their use as accumulation indicators. This covers a wide range of applications within the scope of environmental and pollutant monitoring. Areas of application include, for example, the chronological tracking of environmental pollution following hazardous incidents, monitoring of the success of regulatory measures and voluntary restrictions, emission and immission monitoring, monitoring of contaminated sites, provision of samples retained for long-term monitoring, and initial exploratory studies for determination of pollution hotspots.

Currently, the use of living organisms for biomonitoring is imperative to protect human and environmental health. Nonetheless, the long-term goal is to replace the use of animals by alternative procedures as far as possible. The European Directive on the protection of animals used for scientific purposes (Directive 2010/63/EU) provides a framework to balance this conflict. Since alternative approaches have not yet been standardized and validated in the field of environmental monitoring, such methods are not covered by the new guideline VDI 4230 , Part 4.

Since the rules and provisions for use of fish as general effect indicators differ substantially, a separate guideline for standards in effect monitoring is under preparation (VDI 4230, Part 5).

\section{Authors' contributions}

All authors listed participated in the design and coordination of the manuscript and helped to draft the manuscript. All authors read and approved the final manuscript.

\section{Authors' information}

Th. Braunbeck is an Associate Professor of Zoology and Ecology at The Centre for Organismal Studies, Faculty of Biosciences at the University of Heidelberg, Germany. He has specialized in ecotoxicology and environmental monitoring and restoration.

J. Gercken is a team leader for Ecotoxicology at the Institute for Applied Ecosystem Research (IFAÖ, Neu Broderstorf, Germany). His main research areas are contaminant monitoring and application of biomarkers in aquatic organisms.

H. Löffler is a biologist and served the Institute for Lake Research, Lake Constance (part of the State Institute for the Environment, Measurements and Nature Conservation of Baden-Wuerttemberg, Germany, in the following areas since 1976: fish ecology and fishery management; limnology and lake restoration.

K.T. von der Trenck is a (bio)chemist and toxicologist. Since 1988, he has served the State Institute for the Environment, Measurements, and Nature Conservation of Baden-Württemberg, Germany, in the following areas: assessment of fate and effects of environmental contaminants; elaboration of cleanup goals and screening levels for contaminated soil, groundwater, and air; biomonitoring of chemical pollutants in bird eggs, earth worms, and standardized grass cultures.

R. Klein is an Associate Professor of Biogeography at the Trier University. His research focuses on the assessment of the environmental state, biomonitoring, and environmental specimen banks. He has been familiar with the development of guidelines for more than 20 years.

\section{Author details \\ ${ }^{1}$ Department of Biogeography, University of Trier, Universitätsring 15, 54286 Trier, Germany. ${ }^{2}$ Institute of Applied Ecology, Alte Dorfstraße 11, 18184 Neu Broderstorf, Germany. ${ }^{3}$ Institute for Lake Research, State Institute for the Environment, Measurements and Conservation in Baden Württem- berg, Argenweg 50/1, 88085 Langenargen, Germany. ${ }^{4}$ State Institute for the Environment, Measurements and Conservation in Baden Württemberg, Gries- bachstr. 1, 76185 Karlsruhe, Germany. ${ }^{5}$ Aquatic Ecology and Toxicology Group, Center for Organismal Studies, University of Heidelberg, Im Neuenheimer Feld 504, 69120 Heidelberg, Germany.}

\section{Acknowledgements}

The authors would like to thank VDI (The Association of German Engineers) for technical and organizational support.

\section{Competing interests}

The authors declare that they have no competing interests.

Received: 28 January 2016 Accepted: 1 April 2016

Published online: 04 May 2016

\section{References}

1. EU (2010) Directive 2000/60/EC of the European Parliament and of the Council of 23 October 2000 establishing a framework for Community action in the field of water policy. Off J Eur Com L 327/1

2. LAWA-AO (2011) Arbeitspapier IV.3: Konzeption für Biota-Untersuchungen zur Überwachung von Umweltqualitätsnormen gemäß RL 2008/105/EG. LAWA-AO Rahmenkonzeption Monitoring; Teil B: Bewertungsgrundlagen und Methodenbeschreibungen, $\mathrm{p} 11$

3. EU (2008) Richtlinie 2008/105/EG des Europäischen Parlaments und des Rates vom 16. Dezember 2008 über Umweltqualitätsnormen im Bereich der Wasserpolitik und zur Änderung und anschließenden Aufhebung der Richtlinien des Rates 82/176/EWG, 83/513/EWG, 84/156/EWG, 84/491/ 
EWG und 86/280/EWG sowie zur Änderung der Richtlinie 2000/60/EG Off J Eur Com L 348/84

4. EU (2013) Richtlinie 2013/39/EU des Europäischen Parlaments und des Rates vom 12. August 2013 zur Änderung der Richtlinien 2000/60/EG und 2008/105/EG in Bezug auf prioritäre Stoffe im Bereich der Wasserpolitik. Off J Eur Com L 226/1
5. Koschorreck J, Heiss C, Wellmitz J, Fliedner A, Rüdel H (2015) The use of monitoring data in EU chemicals management-experiences and considerations from the German environmental specimen bank. Environ Sci Pollut Res Int 22:1597-1611

\section{Submit your manuscript to a SpringerOpen ${ }^{\odot}$ journal and benefit from:}

- Convenient online submission

\section{- Rigorous peer review}

- Immediate publication on acceptance

- Open access: articles freely available online

- High visibility within the field

- Retaining the copyright to your article 